Article

\title{
Particulate Emissions of Euro 4 Motorcycles and Sampling Considerations
}

\author{
Barouch Giechaskiel ${ }^{1, *}$, Alessandro A. Zardini ${ }^{1}$, Tero Lähde ${ }^{1}$, Adolfo Perujo ${ }^{1}$, \\ Anastasios Kontses ${ }^{2}$ and Leonidas Ntziachristos ${ }^{2}$ (D) \\ 1 European Commission-Joint Research Centre, 21027 Ispra (VA), Italy \\ 2 Laboratory of Applied Thermodynamics, Aristotle University Thessaloniki, 54124 Thessaloniki, Greece \\ * Correspondence: barouch.giechaskiel@ec.europa.eu; Tel.: +39-0332-78-5312
}

Received: 28 June 2019; Accepted: 19 July 2019; Published: 21 July 2019

\begin{abstract}
The scientific literature indicates that solid particle number (SPN) emissions of motorcycles are usually higher than that of passenger cars. The L-category (e.g., mopeds, motorcycles) Euro 4 and 5 environmental steps were designed to reduce the emissions of particulate matter and ozone precursors such as nitrogen oxides and hydrocarbons. In this study the SPN emissions of one moped and eight motorcycles, all fulfilling the Euro 4 standards, were measured with a SPN measurement system employing a catalytic stripper to minimize volatile artefacts. Although the particulate matter mass emissions were $<1.5 \mathrm{mg} / \mathrm{km}$ for all vehicles tested, two motorcycles and the moped were close to the SPN limit for passenger cars $\left(6 \times 10^{11}\right.$ particles $/ \mathrm{km}$ with sizes larger than $\left.23 \mathrm{~nm}\right)$ and four motorcycles exceeded the limit by a factor of up to four. The measurement repeatability was satisfactory (deviation from the mean 10\%) and concentration differences between tailpipe and dilution tunnel were small, indicating that performing robust SPN measurements for regulatory control purposes is feasible. However, steady state tests with the moped showed major differences between the tailpipe and the dilution tunnel sampling points for sub- $23 \mathrm{~nm}$ particles. Thus, the measurement procedures of particles for small displacement engine mopeds and motorcycles need to be better defined for a possible future introduction in regulations.
\end{abstract}

Keywords: air pollution; powered two-wheelers; L-category; solid particle number (SPN); particulate matter (PM) mass; artefacts; tailpipe; dilution tunnel (CVS); WMTC; sub-23 nm

\section{Introduction}

Particulate matter (PM) is damaging to ecosystems and cultural sites, responsible for reduced visibility and an important global risk factor for human health [1]. Ultrafine particles (particles with diameter smaller than $100 \mathrm{~nm}$ ) typically provide the greatest contribution to total particle count, especially in urban environments [2,3], but a very small contribution to total volume and mass [3,4]. Ultrafine particles have been associated with short-term cardiorespiratory and central nervous system adverse health effects [5]. Clinical and toxicological studies have shown that ultrafine particles can act through mechanisms that are not shared with larger particles [4]. For this reason, surface area or particle number concentrations may be better predictors of health effects than mass concentration $[4,6]$. The ultrafine particles in urban areas can either be primary particles from emission sources such as traffic [2,4,7], or secondary particles formed by gaseous precursors [8], with the internal combustion engines being a major source of these precursors [9].

Automotive exhaust PM, due to its important contribution to ambient PM [10], has been subject to continuously more stringent regulations worldwide. PM mass emissions are determined worldwide gravimetrically by collecting diluted exhaust gas on a filter [11]. In addition to the PM method, in the European Union (EU), a non-volatile (solid) particle number (SPN) method is enforced for 
light-duty and heavy-duty vehicles. Under this method, particles with diameter $>23 \mathrm{~nm}$ surviving a thermal pretreatment stage at $350{ }^{\circ} \mathrm{C}$ are considered to be non-volatile particles [12]. The SPN limit value for passenger cars is $6 \times 10^{11}$ particles per $\mathrm{km}(\mathrm{p} / \mathrm{km}$ from now on) [13]. The SPN regulation was initially applicable to light-duty diesel vehicles, but subsequently covered on-road and off-road heavy-duty engines and also gasoline direct injection light-duty vehicles, as well as inland navigation vessels. Recently, the European Commission decided to extend the lowest detection size of the SPN methodology to $10 \mathrm{~nm}$ [14], to cover cases that have a high fraction of particles in the $10 \mathrm{~nm}$ to $23 \mathrm{~nm}$ size range (e.g., some vehicles with spark ignition engines) [15-17].

One source of ultrafine particles are mopeds (engine displacement $<50 \mathrm{~cm}^{3}$ ) and motorcycles, collectively called powered two-wheelers (PTW). The registered PTW accounted for 33.8 million vehicles in EU-28 in 2016, about $10 \%$ of the passengers mobility fleet $[18,19]$. In Italy the registered PTW in 2016 were more than 9 million, or 27\% of the EU-28 PTW fleet. The year 2018 closed with a $10 \%$ increase and a $31 \%$ decrease of motorcycles and moped new vehicle registrations, respectively, compared to 2017. During the first 3 months of 2019, the registrations of mopeds and motorcycles increased compared to the registration levels of the same period in 2018. This means that the EU PTW circulating fleet is increasing, as well as the share of motorcycles compared to mopeds [20].

In 1997, Directive 97/24/EC implemented Euro 1 standards to reduce air pollutant emissions from two- and three-wheel vehicles, which are referred to in later directives as Category $\mathrm{L}$ vehicles. Directive 2002/51/EC and Directive 2003/77/EC introduced the Euro 2 and 3 standards for motorcycles; the latter further tightened with a new driving cycle introduced by Directive 2006/72/EC. The Euro 3 package, in particular, included motorcycle emissions at cold engine start (cold start emissions, hereon) as part of the type-approval procedure. The cold start test was extended to the moped later in 2014. Regulation (EU) No 168/2013 in 2013 and supplemental technical Regulation (EU) 134/2014 in 2014 repealed previous EU legislation on L-category by implementing the Euro 4 (2016-2017) and Euro 5 (2020-2021) packages which among other provisions: 1 ) introduced a new emission test cycle for some vehicle types, 2) tightened the gaseous compounds emission limits, 3) expanded the number of L-subcategories, and 4) introduced a PM limit. The scope was to keep constant or reduce the share of total road-transport emissions from L-category vehicles as compared to other road vehicle categories with a focus on PM and ozone precursors such as nitrogen oxides and hydrocarbons. The PM mass limit was set for compression ignition (CI) and CI/hybrid vehicles at a lenient level of $80 \mathrm{mg} / \mathrm{km}$ in Euro 4 and reduced to $4.5 \mathrm{mg} / \mathrm{km}$ (the same as for passenger cars) in Euro 5 with extension to gasoline direct injection engines.

The relative contribution of mopeds and motorcycles to PM emissions started to increase as the levels from other vehicles started to decrease. The particulate emissions of two-stroke PTW have been studied by many researchers (e.g., references [21-37]) exceeding $100 \mathrm{mg} / \mathrm{km}$ and $10^{13} \mathrm{p} / \mathrm{km}$ in most cases. Two-stroke mopeds emit significant amounts of aromatic volatile organic compounds and also produce significant secondary organic aerosol [9,34]. Four-stroke mopeds [26,27,33,34,38,39] and motorcycles $[23,29,35-37,40-43]$ have generally lower SPN emissions, but in most cases above the limit applicable for passenger cars. Data for the latest Euro 4 PTW are limited (e.g., reference [44]). Most importantly, there is neither a legislated nor a standardized procedure to measure particle number emissions for this category of vehicles. Regulation (EU) 168/2013 required an ex-post environmental effect study [45] which should inter alia assess the feasibility of a SPN limit for L-category [46]. In the absence of a standardized procedure, some researchers sample from the tailpipe (e.g., reference [24,26]), while others from the full dilution tunnel without specifying lengths and residence times in the tubing (e.g., reference [46]). Physical processes such as particle agglomeration, diffusion and thermophoresis can decrease the concentration from the tailpipe to the dilution tunnel $[17,47,48]$. Desorption of semi-volatile components from this tubing can also result in volatile artefacts, i.e. re-nucleation of volatile species downstream of the evaporation tube that are counted as solid particles $[46,49]$. The objective of this paper is to present particulate emissions of Euro 4 PTW in terms of PM mass and SPN. In addition, particles below the current lower size defined in the passenger cars regulation 
( $23 \mathrm{~nm}$ ) will be investigated, because high sub-23 $\mathrm{nm}$ fractions have been reported for this category of vehicles $[16,44,46]$. Potential issues with SPN measurements for future regulations will also be discussed.

\section{Experiments}

The tests were conducted in the Vehicle Emissions Laboratory (VELA 1) of the European Commission-Joint Research Centre (JRC) in Ispra, Italy. VELA 1 is a climatic emission test cell with a single axis roller dynamometer used for passenger cars and motorcycles. The exhaust of the vehicles was connected to a full dilution tunnel with constant volume sampling (CVS) (Figure 1). All connections were with stainless steel parts. No elastomers were used because at high temperatures they can release semi-volatile species that could affect the mass or number measurements and they are not allowed in the light-duty vehicles regulations. The flow rate of the CVS was $5.5 \mathrm{~m}^{3} / \mathrm{min}(0.12 \mathrm{~kg} / \mathrm{s})$. The temperature of the cell was $23-25^{\circ} \mathrm{C}$.

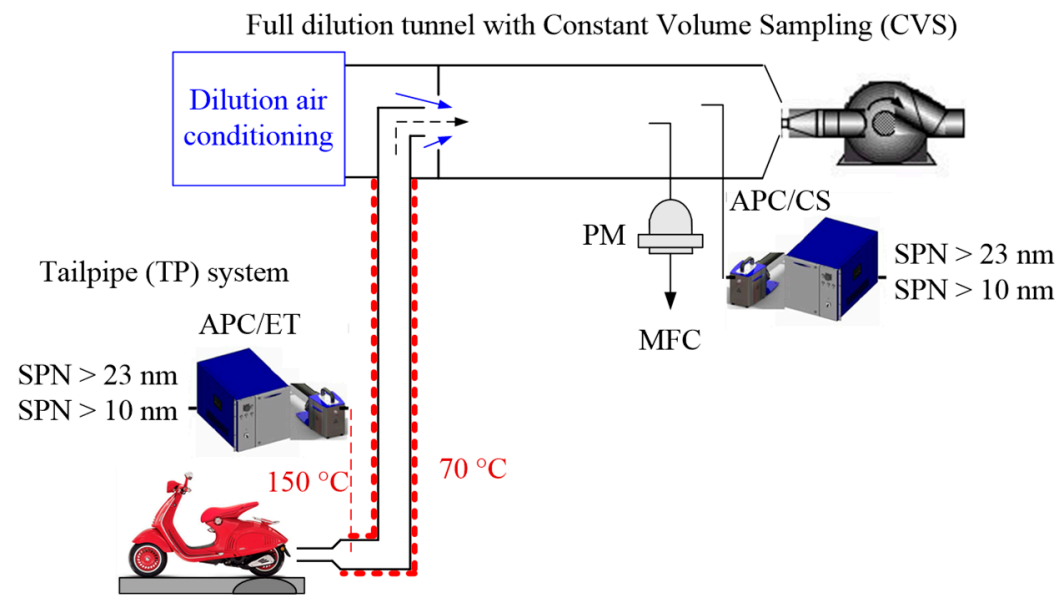

Figure 1. Experimental setup. SPN $=$ Solid particle number; $\mathrm{APC}=\mathrm{AVL}$ particle counter; ET $=$ Evaporation tube; $\mathrm{CS}=$ Catalytic stripper; $\mathrm{PM}=$ Particulate matter; $\mathrm{MFC}=$ Mass flow controller.

The PM mass was determined with filter measurements, as described in the Regulation (EU) 2014/134. The flow rate through the filter was $50 \mathrm{~L} / \mathrm{min}$. TX40 filters of $47 \mathrm{~mm}$ diameter were used.

The SPN measurement system connected to the dilution tunnel was the AVL particle counter (APC) 489 (AVL, Graz, Austria), compliant with the light-duty vehicle regulations [50]. Previous studies suggest that both solid and volatile artefacts appear in SPN systems when $10 \mathrm{~nm}$ measurements are conducted and catalytic strippers are recommended for sub-23 nm measurements [51]. For this reason, the volatile particle remover (VPR) of the measurement system consisted of a hot diluter kept at $150{ }^{\circ} \mathrm{C}$, a catalytic stripper at $350{ }^{\circ} \mathrm{C}$ [52], and a final porous diluter operating with room-temperature filtered air. The system was calibrated by the manufacturer. The so called particle number concentration reduction factor (PCRF) that expresses concentration reduction due to the combined effects of dilution and average particle losses at $30 \mathrm{~nm}, 50 \mathrm{~nm}$ and $100 \mathrm{~nm}$, was approximately $250(25 \times 10)$. Downstream of the VPR a butanol condensation particle counter (CPC) (model TSI 3790) [53,54] with 50\% counting efficiency at $23 \mathrm{~nm}$ and a butanol CPC (model TSI 3772) [55] with 50\% counting efficiency at $10 \mathrm{~nm}$ were connected to measure solid particles. No additional particle losses for sub- $23 \mathrm{~nm}$ particles were applied. The additional particles below $23 \mathrm{~nm}$ reported in this work (i.e. the difference of the $10 \mathrm{~nm}$ and $23 \mathrm{~nm} \mathrm{CPCs)} \mathrm{would} \mathrm{be} 1.7$ times higher with loss correction [17]. The additional particles that reside below $23 \mathrm{~nm}$ were calculated as:

$$
\text { Additional sub-23 } \mathrm{nm}=\mathrm{SPN}_{10} / \mathrm{SPN}_{23}-1
$$


In order to investigate the differences between tailpipe and CVS measurements, an identical combination of instruments was connected to the tailpipe with a $0.5 \mathrm{~m}$ heated line at $120^{\circ} \mathrm{C}$ for a few tests using moped \#1 and motorcycle \#8 (see details below). Due to limited instrument availability, instead of catalytic stripper, an evaporation tube was included as a VPR. In order to minimize artefacts [56], we used high primary dilution (200) with a total PCRF of the system at the tailpipe of $2000(200 \times 10)$.

The powered two-wheelers (PTW) that were tested are summarized in Table 1. Three of them $(\# 6, \# 7, \# 9)$ were used in another study [44] where results had been averaged with older vehicles of the same category and presented in aggregated form. In this study we instead used disaggregated results, and a particle counting system with additionally a catalytic stripper. The following subcategories were covered (definitions according to Regulation 168/2013):

- 2-wheel mopeds (L1e-B) with engine displacement $\leq 50 \mathrm{~cm}^{3}$, maximum speed $\leq 45 \mathrm{~km} / \mathrm{h}$, and power $\leq 4 \mathrm{~kW}$.

- Low performance motorcycles (L3e-A1) with engine displacement $\leq 125 \mathrm{~cm}^{3}$, power/weight ratio $\leq 0.1 \mathrm{~kW} / \mathrm{kg}$, and maximum power $\leq 11 \mathrm{~kW}$.

- Medium performance motorcycles (L3e-A2) with power/weight ratio $\leq 0.2 \mathrm{~kW} / \mathrm{kg}$, and maximum power $\leq 35 \mathrm{~kW}$.

- High performance motorcycles (L3e-A3) with power/weight ratio $>0.2 \mathrm{~kW} / \mathrm{kg}$, and maximum power $>35 \mathrm{~kW}$.

Table 1. Characteristics of the Powered Two-Wheelers (PTW). All Euro 4 gasoline 4-stroke engines with port fuel injection and three-way catalyst as exhaust after-treatment. Fuel E5.

\begin{tabular}{cccccccccc}
\hline Code & Category & $\begin{array}{c}\text { Power } \\
(\mathbf{k W})\end{array}$ & $\begin{array}{c}\text { Displ. } \\
\mathbf{( c m}^{\mathbf{3}} \mathbf{)}\end{array}$ & MY & TR & $\begin{array}{c}\text { Max Speed } \\
(\mathbf{k m} / \mathbf{h})\end{array}$ & $\begin{array}{c}\text { Mileage } \\
\mathbf{( k m})\end{array}$ & $\begin{array}{c}\text { Mass } \\
\mathbf{( k g})\end{array}$ & $\begin{array}{c}\text { Power/Mass } \\
\mathbf{( k W / k g})\end{array}$ \\
\hline$\# 1$ & L1e-B & 2.4 & 50 & 2018 & CVT & 45 & 500 & 98 & 0.02 \\
$\# 2$ & L3e-A1 & 9.0 & 125 & 2016 & MT & 95 & 2350 & 142 & 0.06 \\
$\# 3$ & L3e-A2 & 11.0 & 155 & 2017 & CVT & 101 & 1000 & 157 & 0.07 \\
$\# 4$ & L3e-A2 & 15.6 & 278 & 2018 & CVT & 115 & 300 & 158 & 0.10 \\
$\# 5$ & L3e-A2 & 18.5 & 279 & 2016 & CVT & 128 & 1000 & 179 & 0.10 \\
$\# 6$ & L3e-A2 & 18.5 & 280 & 2015 & CVT & 128 & 3100 & 179 & 0.10 \\
$\# 7$ & L3e-A2 & 32.0 & 693 & 2016 & MT & 120 & 1000 & 162 & 0.20 \\
$\# 8$ & L3e-A3 & 103.0 & 798 & 2018 & MT & $>140$ & 850 & 209 & 0.49 \\
$\# 9$ & L3e-A3 & 92.0 & 1170 & 2015 & MT & $>140$ & 1150 & 254 & 0.36 \\
\hline
\end{tabular}

${ }^{1}$ Mass in running order (including $10 \mathrm{~kg}$ for coolant, oil, fuel). MY = Model year; TR = Transmission; MT = Manual Transmission; CVT = Continuously Variable Transmission.

Reference fuel with 5\% ethanol content was used. The test cycle was the world-harmonised motorcycle test cycle (WMTC) applicable to Euro 4 motorcycles and from 2020 to all Euro 5 PTW. The WMTC consists of 5 different speed profiles depending on maximum vehicle speed and engine displacement and corresponds to the type-approval cycle for all vehicles in Table 1 except for the moped (L1e-B) which was type approved under the UNECE (United Nations Economic Commission for Europe) Regulation 47 procedure. The WMTC and its parts are plotted in Figure 2. Table 2 gives the applicable parts of the test cycle for each PTW. For example, PTW \#4-7 were tested with part 1 (engine cold start) followed by part 2 (warm engine conditions). Details for the UNECE Regulation 47 cycle can be found elsewhere [44,46]. We used the weighting factors of the cold and hot phases (Table 2) for both Euro 4 and Euro 5 specifications in order to explore the impact of future provisions. The weighting factors are legislative prescribed percentages (sum equals $100 \%$ ) that give different importance at the different parts of the test cycle (see Regulation EU 134/2014).

The PCRF corrected concentrations $\left[\mathrm{p} / \mathrm{m}^{3}\right]$ of the CPCs of the system connected to the tailpipe were multiplied by the PTW exhaust flow rate $[\mathrm{kg} / \mathrm{s}]$ (Appendix A) and divided by the exhaust gas density to calculate particles per second $(\mathrm{p} / \mathrm{s})$. The PCRF corrected concentrations of the CPCs of the 
system connected to the dilution tunnel were multiplied by the CVS flow rate $(0.12 \mathrm{~kg} / \mathrm{s})$ and divided by the air density. The applied densities $\left(1.29 \mathrm{~kg} / \mathrm{m}^{3}\right)$ were at the same conditions that the CPCs concentrations were normalised to $\left(0{ }^{\circ} \mathrm{C}, 101.3 \mathrm{kPa}\right)$. The instantaneous values were integrated for each phase and divided with the respective distance. Details can be found elsewhere [17].

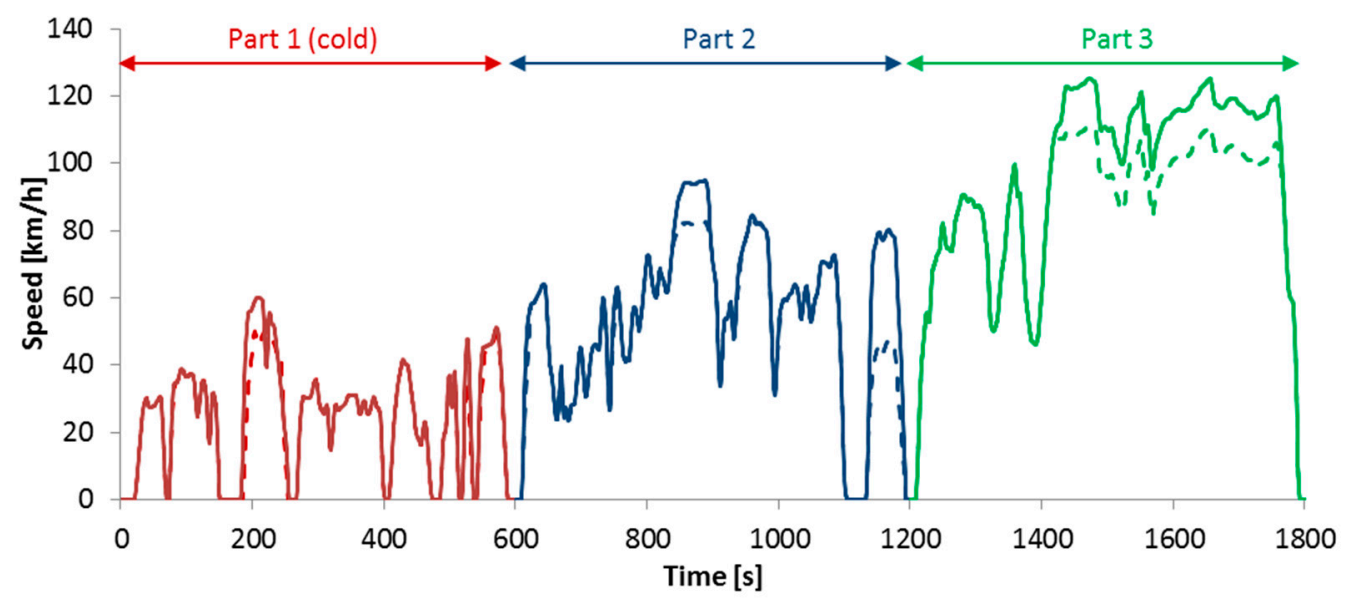

Figure 2. Test cycle (WMTC) and parts. Dashed lines show the reduced speed version.

Table 2. Test cycles for each PTW. P1-P3 refer to parts 1-3 of the driving cycle (Figure 2). Reduced $=$ reduced speed profiles as in Regulation 2014/134.

\begin{tabular}{cccccc}
\hline Code & Category & WMTC & Parts & WF (Euro 4) & WF (Euro 5) \\
\hline$\# 1$ & L1e-B & 1 & P1 + P1 (reduced) & $30-70$ & $50-50$ \\
$\# 2$ & L3e-A1 & 1 & P1 + P1 (reduced) & $30-70$ & $50-50$ \\
$\# 3$ & L3e-A2 & $2-1$ & P1 + P2 (reduced) & $30-70$ & $50-50$ \\
$\# 4$ & L3e-A2 & $2-2$ & P1 + P2 & $30-70$ & $50-50$ \\
$\# 5$ & L3e-A2 & $2-2$ & P1 + P2 & $30-70$ & $50-50$ \\
$\# 6$ & L3e-A2 & $2-2$ & P1 + P2 & $30-70$ & $50-50$ \\
$\# 7$ & L3e-A2 & $2-2$ & P1 + P2 & $30-70$ & $50-50$ \\
$\# 8$ & L3e-A3 & $3-2$ & P1 + P2 +P3 & $25-50-25$ & $25-50-25$ \\
$\# 9$ & L3e-A3 & $3-2$ & P1 + P2 + P3 & $25-50-25$ & $25-50-25$ \\
\hline
\end{tabular}

WF $=$ Weighting factors.

\section{Results}

The PM mass emissions per vehicle are given in Figure 3. For PTW \#5 no PM measurements were taken and for \#4 and \#8 only one filter for the complete cycle. Note that for the PTW specific to this study, no PM mass limit is applicable in Euro 4 or Euro 5 standards. All vehicles emitted $<1.5 \mathrm{mg} / \mathrm{km}$, which is even much below the future Euro 5 PM mass limit for diesel and gasoline direct injection L-category engines. The variability of the measurements expressed as difference of maximum value from the mean of two measurements was on average $28 \%$ (range $8-53 \%$ ) or $0.25 \mathrm{mg} / \mathrm{km}$.

Figure 4 summarizes the SPN emissions measured at the dilution tunnel of all vehicles with the weighting factors of Euro 4 or Euro 5 provisions. The SPN limit for passenger cars is used as a guide to the eye (dashed line) in order to put the PTW levels in context with the existing legislative framework. This level should not be taken as a future PTW limit value or as a threshold which qualifies or disqualifies the environmental performance of the vehicles in this study. 


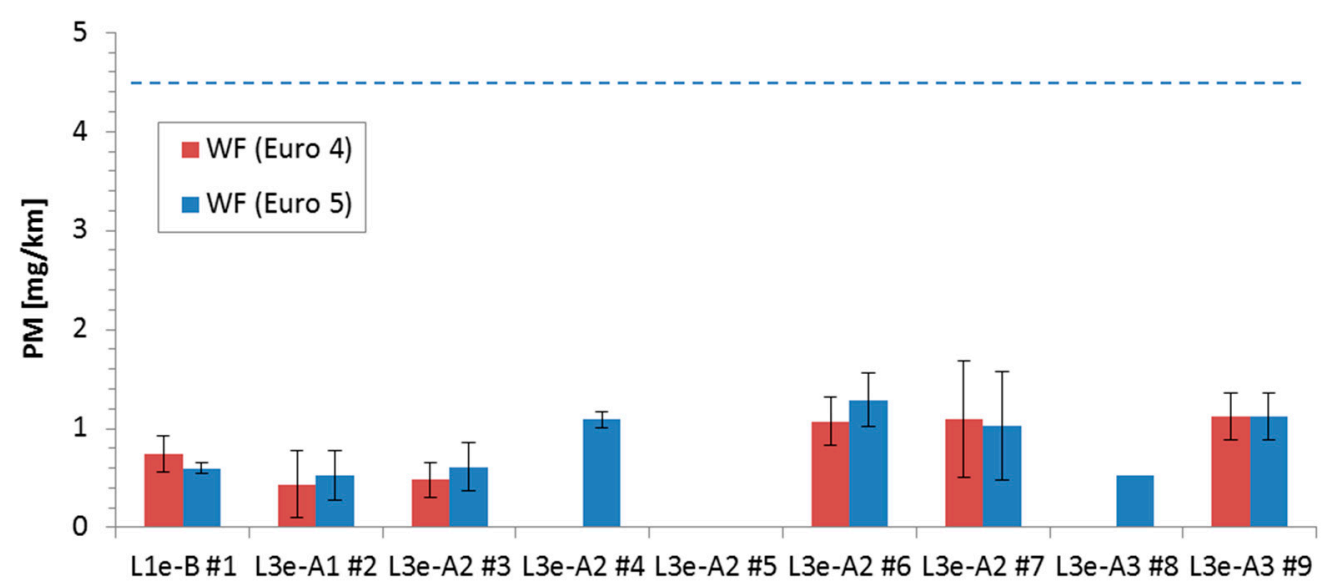

Figure 3. Particulate matter (PM) mass emissions. The cycle tested was the WMTC (Figure 2) with the weighting factors (WF) of Table 2. Exception: L1e-B Euro 4 test cycle was from UNECE Regulation 47. The dashed line shows the PM limit for Euro 5 diesel and gasoline direct injection PTW (and light-duty vehicles). Error bars show min-max values of two repetitions.

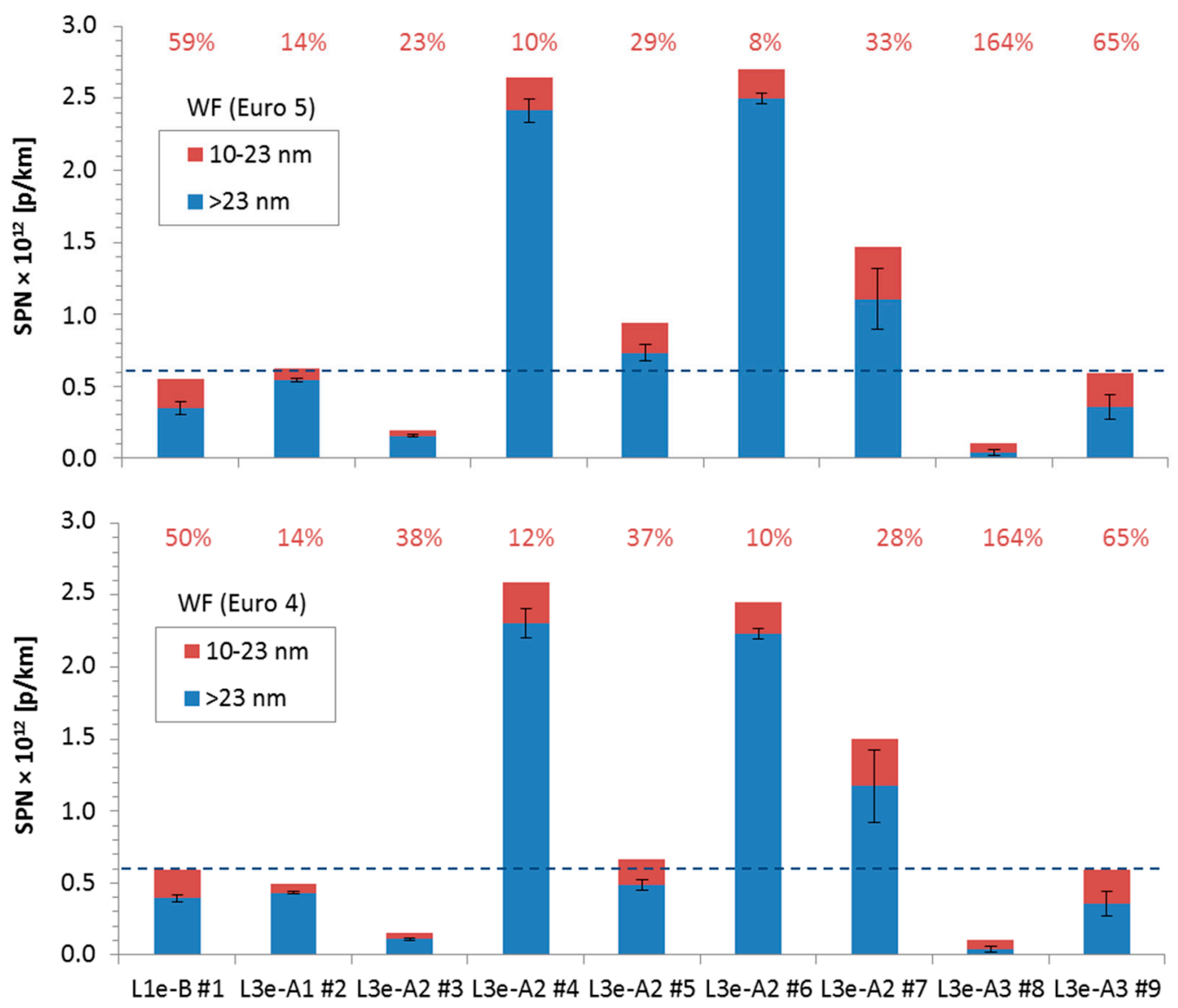

Figure 4. Solid particle number (SPN) emissions. The cycle tested was the WMTC (Figure 2) with the Euro 5 (upper panel) and Euro 4 (lower panel) weighting factors (WF) of Table 2. Exception: L1e-B Euro 4 test cycle was from UNECE Regulation 47. The dashed line shows the SPN > $23 \mathrm{~nm}$ limit for diesel and gasoline direct injection passenger cars. Percentages on top show the additional particles that reside below $23 \mathrm{~nm}$ (Equation (1)).

By applying the Euro 5 weighting factors (upper panel), 4 out of 9 exceed the SPN $>23 \mathrm{~nm}$ limit for passenger cars. Three more PTW were close to the limit when the sub-23 nm particles were 
also considered. The contribution of sub-23 nm particles was 8-65\%, with one exception (164\%) for a low emitting vehicle (L3e-A3). The SPN > $23 \mathrm{~nm}$ emission levels varied from $1.5 \times 10^{11} \mathrm{p} / \mathrm{km}$ to $2.5 \times 10^{12} \mathrm{p} / \mathrm{km}$. There was no particular trend in terms of model year, motorcycle manufacturer, maximum power or engine capacity. Applying the Euro 4 weighting factors (lower panel) the results were similar, indicating that the cold start contribution was small for these PTW. For SPN $>10 \mathrm{~nm}$, the first part was on average $80 \%$ higher than the second part excluding the L3e-A2 \#5 (6 times higher) and the moped (3 times higher).

The variability of the measurements expressed as difference of maximum value from the mean of 2 measurements was on average $10 \%$ (range 1-24\%), with the exception of L3e-A3 \#8 (50\%) where the emissions were very low at $2 \times 10^{10} \mathrm{p} / \mathrm{km}$.

\section{Discussion}

\subsection{Emission Levels}

Figures 5 and 6 summarize the PM mass and SPN (with different lower sizes) emissions respectively reported in the literature for motorcycles (upper panel) and mopeds (lower panel), with 2-stroke (2s) or 4-stroke (4s) engines, with carburettor (carb), direct injection (DI) or port fuel injection (PFI). The emissions are given as a function of the registration year. When the year was not available, it was assumed to be two years before the published year of the specific paper. When the Euro standard was given, the year was adjusted to match the specific Euro period.

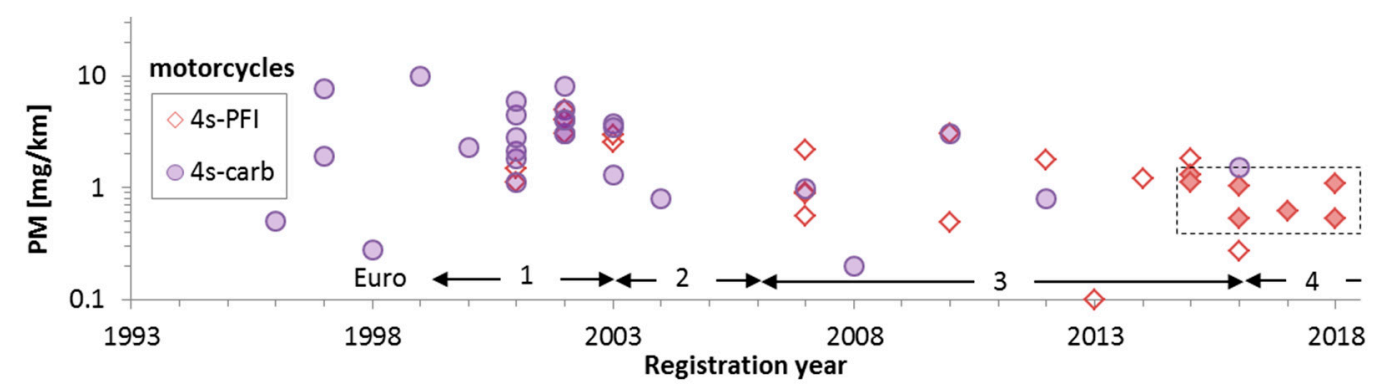

(a)

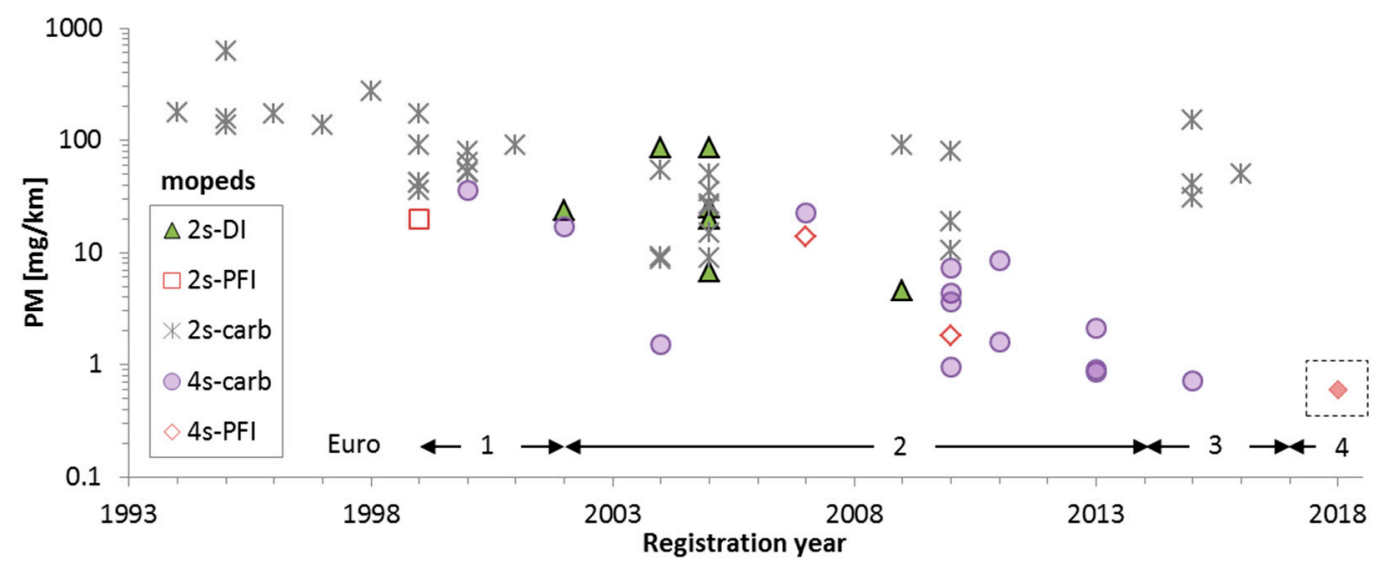

(b)

Figure 5. Particulate matter (PM) mass emissions from the literature (details in text) for (a) motorcycles and (b) mopeds with 2-stroke (2s) or 4-stroke (4s) engines with carburettor (carb), direct injection (DI) or port fuel injection (PFI). The vehicles of this study are in dotted boxes. 

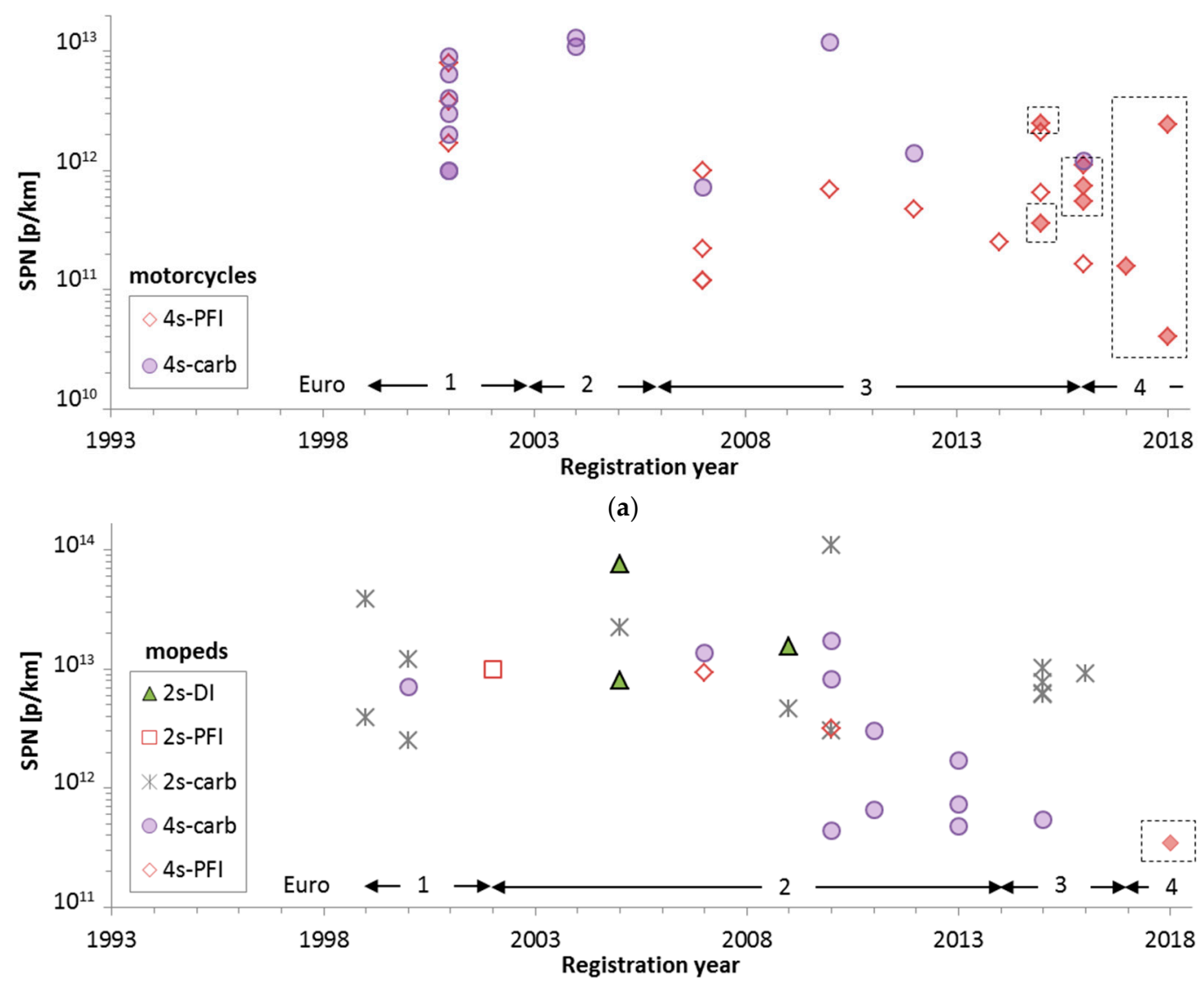

*

$\Delta O$

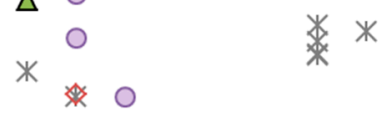

(b)

Figure 6. Solid particle number (SPN) emissions from the literature (details in text) for (a) motorcycles and (b) mopeds with 2-stroke (2s) or 4-stroke (4s) engines with carburettor (carb), direct injection (DI) or port fuel injection (PFI). The vehicles of this study are in dotted boxes.

The PM emission levels of the Euro 4 PTW that we examined were below $<1.5 \mathrm{mg} / \mathrm{km}$ (Figure 5). As far as the authors are aware, there are no literature data on Euro 4 mopeds and very limited data on Euro 4 motorcycles [44], which were included in this paper. Comparing with older type approved mopeds (Euro 2) (Figure 5), the PM mass levels for 4-stroke mopeds, as the one in our study, reported in the literature show large variations: From less than $4.5 \mathrm{mg} / \mathrm{km}[26,27,34,44]$ to higher values [38,39] reaching even $36 \mathrm{mg} / \mathrm{km}$ [33]. The emissions though are much lower than two-stroke mopeds with carburettor $[21-23,25-36,44]$, direct injection $[24,27,30-32,36]$, or port fuel injection $[35,36]$ that can exceed $100 \mathrm{mg} / \mathrm{km}$ in many cases. There is also no clear difference among the different technologies (direct injection, carburettor and port fuel injection) for 2-stroke engines raising concerns that future PM limit will be applied only to positive ignition direct injection engines. However, it is expected that the 2-stroke mopeds market share will be significantly reduced in the Euro 5 step due to their demanding costs to comply with hydrocarbons emission limits [44,45]. The PM mass levels for 4-stroke motorcycles reported in the literature vary in a smaller range: they are typically less than $4.5 \mathrm{mg} / \mathrm{km} \mathrm{[35-37,40-44]}$ but with a few older models with a carburettor [23,37,42] reaching up to $10 \mathrm{mg} / \mathrm{km}$.

The reported SPN emission of 4-stroke mopeds (Euro 2 or before) (Figure 6) range from $4 \times 10^{11} \mathrm{p} / \mathrm{km}$ to $1.7 \times 10^{13} \mathrm{p} / \mathrm{km}[27,33,39,44]$, thus the moped of our study $\left(3.5 \times 10^{11} \mathrm{p} / \mathrm{km}\right)$ was slightly below the low end. The 2-stroke engines have on average higher emissions [21,27,32,33,35,44]. The reported SPN emission of 4-stroke motorcycles range from $10^{11} \mathrm{p} / \mathrm{km}$ to $1.3 \times 10^{13} \mathrm{p} / \mathrm{km}[33,35,37,41,43,44]$. SPN emissions of the Euro 4 motorcycles in our study ranged from $4 \times 10^{10} \mathrm{p} / \mathrm{km}$ to $2.5 \times 10^{12} \mathrm{p} / \mathrm{km}$, indicating that emissions have decreased with technology improvements. The likely cause is the reduction in total hydrocarbons from Euro 2 to Euro 4 [44] that also requires better control of fuel 
enrichment during transients. It should also be mentioned that in some literature instances the reported emissions were without any thermal pre-treatment, thus emission levels might have appeared to be higher due to the presence of the volatile nucleation mode. In addition, in our tests we used a catalytic stripper which is less prone to artefacts, while other studies with evaporation tube and lower size limit below $23 \mathrm{~nm}$ overestimate the emissions due to artefacts $[44,46]$.

\subsection{Correlation PM-SPN}

Figure 7 shows the correlation between integrated PM mass and dilution tunnel SPN $>23 \mathrm{~nm}$ over the different parts and total duration of WMTC. Considering only the data from the first two parts, the slope is $1.2 \times 10^{12} \mathrm{p} / \mathrm{mg}$ which is at the low end of the range reported for passenger cars and heavy-duty vehicles $\left(1-4 \times 10^{12} \mathrm{p} / \mathrm{mg}\right)[12,57]$. The low value indicates that the PM mass comprises a significant fraction of volatile species, originating either from the PTW emissions or the sampling system as such. The so called "filter artefact" for TX40 filters is well known and has been reported to be around $1 \mathrm{mg} / \mathrm{km}[12,58,59]$. It is unlikely that the low slope was due to large particles, typically seen with 2-stroke engines, because it is not common for 4-stroke engines [46]. The high SPN emitting vehicles (\#4 and \#6) lie above the correlation line. The point of the 3rd phase shows a high mass compared to the number of solid particles. The high mass could be attributed to released material from the sampling lines or incomplete combustion at the high speed (and exhaust gas temperatures) part of the cycle.

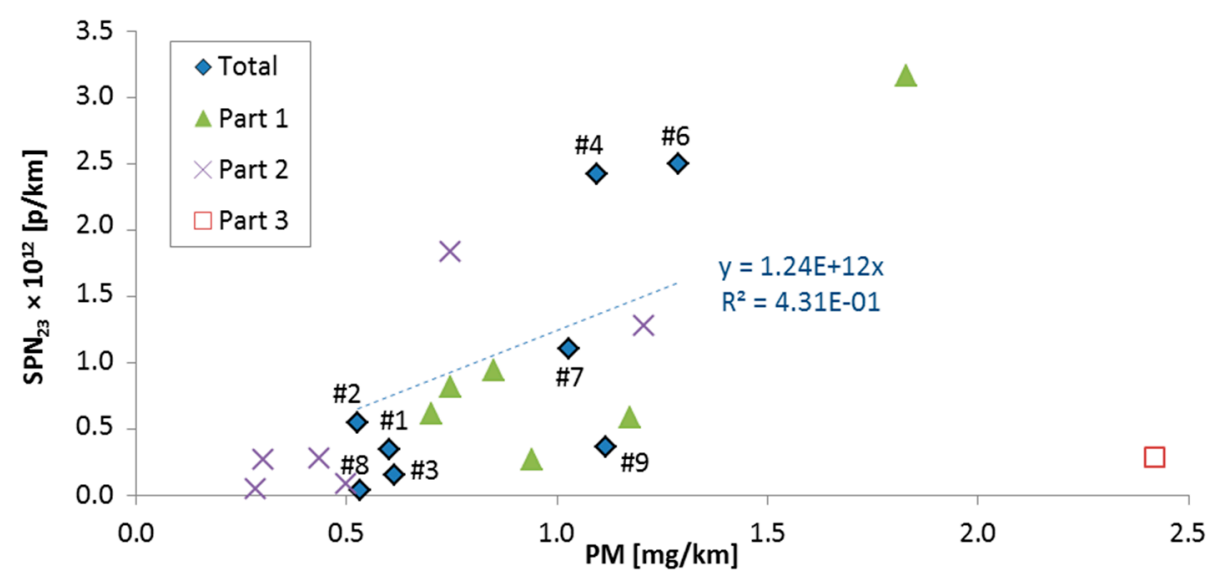

Figure 7. Correlation of particulate matter (PM) mass and solid particle number (SPN) emissions $(>23 \mathrm{~nm}$ ). The cycle tested was the WMTC (Figure 2) with the Euro 5 weighting factors of Table 2.

Using the $1.2 \times 10^{12} \mathrm{p} / \mathrm{mg}$ value, a SPN limit of $6 \times 10^{11} \mathrm{p} / \mathrm{km}$ translates to a PM mass limit of approximately $0.5 \mathrm{mg} / \mathrm{km}$ which is much lower than the $4.5 \mathrm{mg} / \mathrm{km}$ limit for Euro 5 diesel and gasoline direct injection L-category engines. In addition, the $0.5 \mathrm{mg} / \mathrm{km}$ level is close to the background levels of the facilities of our study. Finally, the scatter of the points is high $\left(R^{2}=0.43\right)$, which makes it difficult to draw a clear conclusion regarding a possible PM limit that could also ensure low SPN emissions (e.g., less than $6 \times 10^{11} \mathrm{p} / \mathrm{km}$ ). Thus, for L-category vehicles, as with the rest vehicle categories (light-duty vehicles, heavy-duty engines), PM mass and SPN should be treated separately.

\subsection{Sub-23 nm Fractions}

The additional particles below $23 \mathrm{~nm}(8-65 \%)$ was given in Figure 4. For Euro 4 vehicles, this was within the range reported for older L-category vehicles [46]. Generally, spark ignition vehicles exhibit higher ratios of sub-23 nm particles, compared to vehicles with compression ignition engines. This indicates that efficient control of particle number emissions for L-category vehicles should be extended to smaller particle sizes (e.g., >10 nm). 
Some steady state tests were conducted to further investigate whether the fraction of particles below $23 \mathrm{~nm}$ depends on tailpipe and operation conditions. Figure 8 plots emission rates of an L3e-A3 vehicle (\#8 in Table 1), with particle samples being collected at the tailpipe.

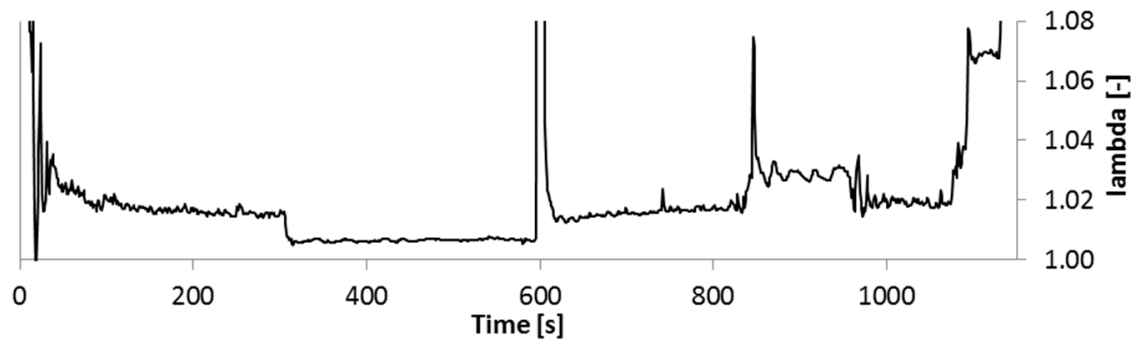

(a)

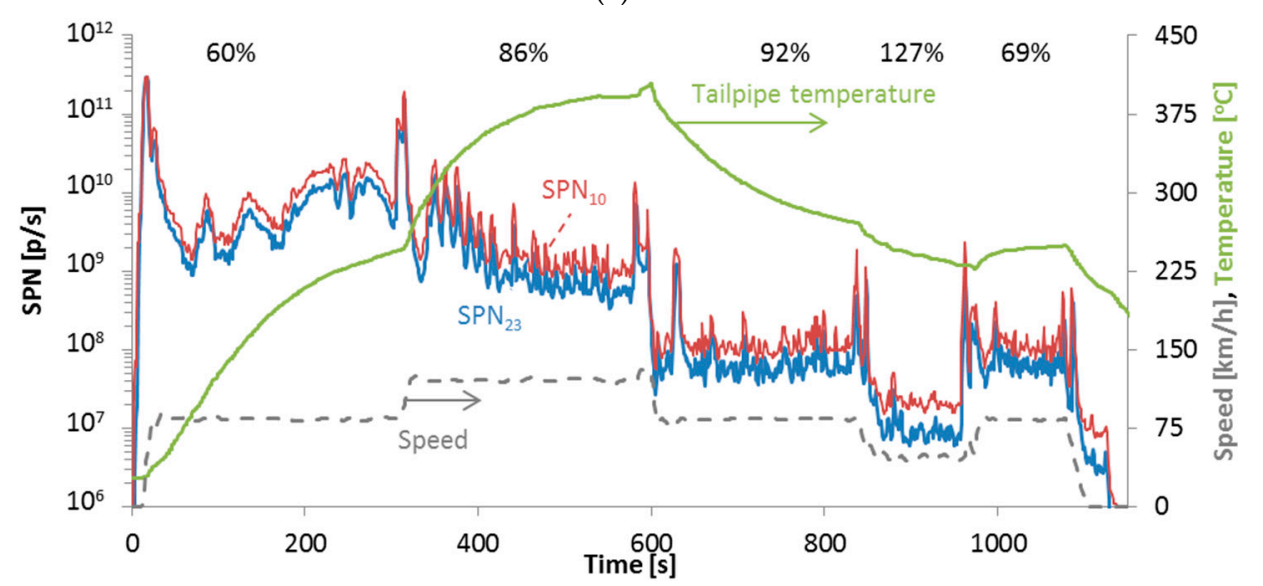

(b)

Figure 8. (a) Lambda; (b) solid particle number (SPN) emissions $>23 \mathrm{~nm}$ and $>10 \mathrm{~nm}$ measured at the tailpipe for L3e-A3 \#8. Percentages give the additional particles $<23 \mathrm{~nm}$. Speed and exhaust gas temperature are also shown.

The additional particles below $23 \mathrm{~nm}$, for the last minute of each speed, range from $60 \%$ to $127 \%$ of the $>23 \mathrm{~nm}$ emissions, depending on the point considered. The differences of the fractions and the absolute levels and can be justified by the slightly different engine operations (see lambda values at 120, 85 and $45 \mathrm{~km} / \mathrm{h}$, which were however always $>1$ ), i.e., the engine was running lean with small excess of air that assists the full oxidation of combustion products. For the speed that was tested three times $(85 \mathrm{~km} / \mathrm{h})$ under different tailpipe temperature conditions, that fraction ranged between $60 \%$ and $92 \%$. In the three cases the lambda remained the same, indicating that the exhaust gas temperature affected the sizes of the particles and consequently the fraction below $23 \mathrm{~nm}$.

Figure 9 (upper panel) shows the SPN concentrations as measured at the CVS for an L3e-A2 vehicle (\#4 in Table 1). For the two first speed points shown $(75 \mathrm{~km} / \mathrm{h}$ and $95 \mathrm{~km} / \mathrm{h})$ the concentration of particles above $23 \mathrm{~nm}$ and $10 \mathrm{~nm}$, as measured with a sampling system employing and evaporation tube (ET), are at the same levels (additional particles $<23 \mathrm{~nm}$ around 35\%). At the max speed of this motorcycle $(115 \mathrm{~km} / \mathrm{h})$, the concentration of particles above $10 \mathrm{~nm}$ was found more than 3 times higher compared to that of particles above $23 \mathrm{~nm}$.

This finding was observed regardless of whether an evaporation tube or a catalytic stripper were used to thermally treat the aerosol samples. Hence, this cannot be considered as a volatile artefact of the measurement system. It is unlikely that the rich operation of the motorcycle for the specific speed and the incomplete combustion increased the small particles (Figure 9, lower panel). They are probably a non-volatile artefact, as will be discussed in the next section. 


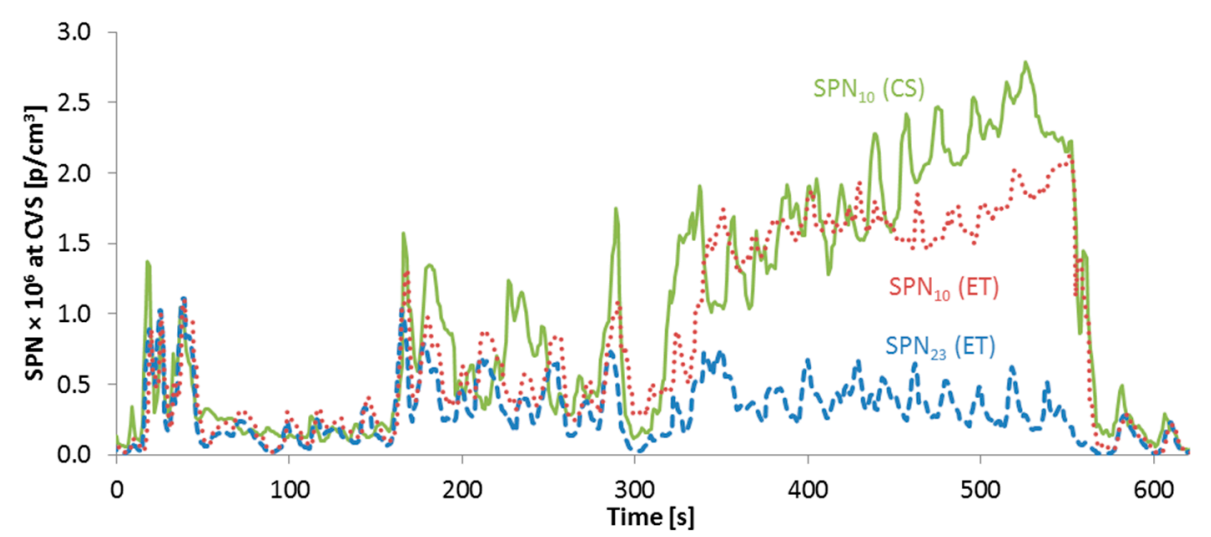

(a)

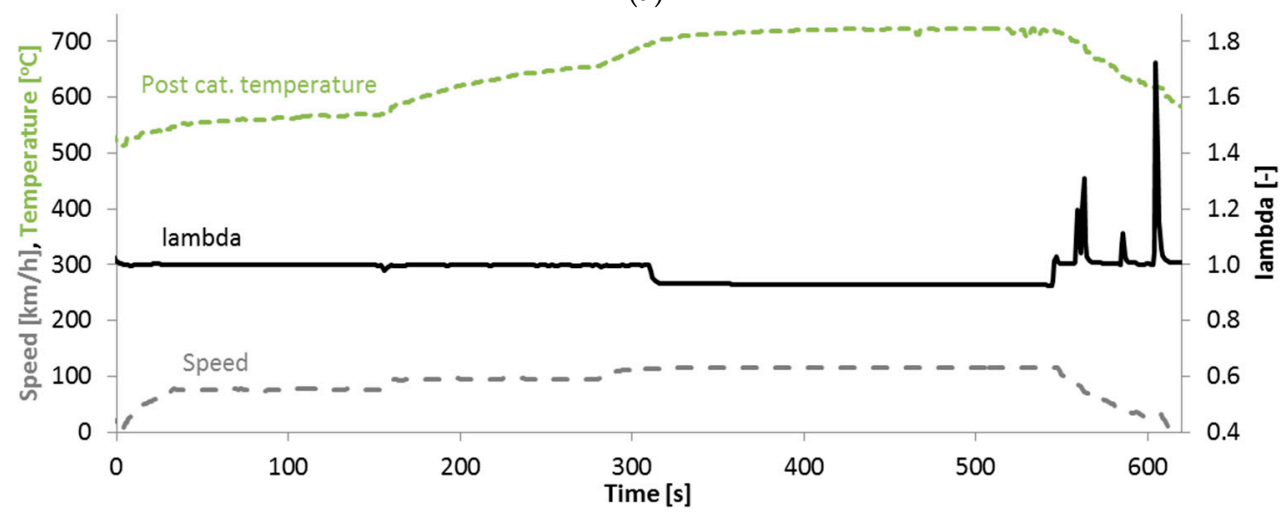

(b)

Figure 9. Solid particle number (SPN) concentrations at the dilution tunnel during a constant speed test with L3e-A2 \#4 using a system with evaporation tube (ET) or a system with catalytic stripper (CS). Small differences at the traces are because the tests were conducted on different days.

\subsection{Tailpipe vs. Dilution Tunnel}

The SPN methodology sampling from the dilution tunnel was initially developed for diesel passenger cars based on the general configuration of existing test facilities [12]. However, measurements directly at the tailpipe are still crucial in assessing exhaust emissions both for research activities and for type-approval. For instance, real-driving emission measurements from the tailpipe are conducted with portable emissions measurement systems (PEMS). Additionally, laboratory tailpipe measurements are allowed for small gasoline utility engines type approval and are under discussion for heavy-duty engines type approval in EU. Recent studies with light-duty vehicles showed the equivalency of the two sampling locations with small differences due to particle losses or exhaust flow inaccuracies $[17,48]$. On the other hand, it was also shown that big differences can be seen, especially for mopeds, due to volatile $[15,46,49]$ or non-volatile artefacts [60]. Thus, it is necessary to further investigate the topic for PTW.

Figure 10 plots the SPN $>10 \mathrm{~nm}$ from the tailpipe and the full dilution tunnel (CVS) for constant speed tests of the L3e-A3 \#8 vehicle; the same one presented in Figure 8. The CVS background level is around $2 \times 10^{8} \mathrm{p} / \mathrm{s}$ (equivalent to $8 \times 10^{8} \mathrm{p} / \mathrm{km}$ ) and interferes with actual emission levels at $45 \mathrm{~km} / \mathrm{h}$, which are low, resulting to a big difference (500\%) between measured emissions levels at the CVS and the tailpipe. For the two first speeds, where the concentration is 10 times higher than the background, the difference between CVS and tailpipe is $16-80 \%$. Such a range can typically be attributed to instrument and exhaust flow rate measurement uncertainties. For this $800 \mathrm{~cm}^{3}$ motorcycle, the exhaust flow rate measurement should be accurate within $10 \%$ and the typical measurement uncertainty between different particle counters is also within $10 \%$. Processes such as thermophoresis, diffusion and agglomeration would further decrease the CVS results $[17,47,48]$. Condensation on 
particles with an original size at tailpipe conditions below $10 \mathrm{~nm}$ may take place within the transfer tube to the CVS and the CVS and bring them within the size range of the measuring instrumentation. This would be reflected to higher number counts at CVS compared to the tailpipe.

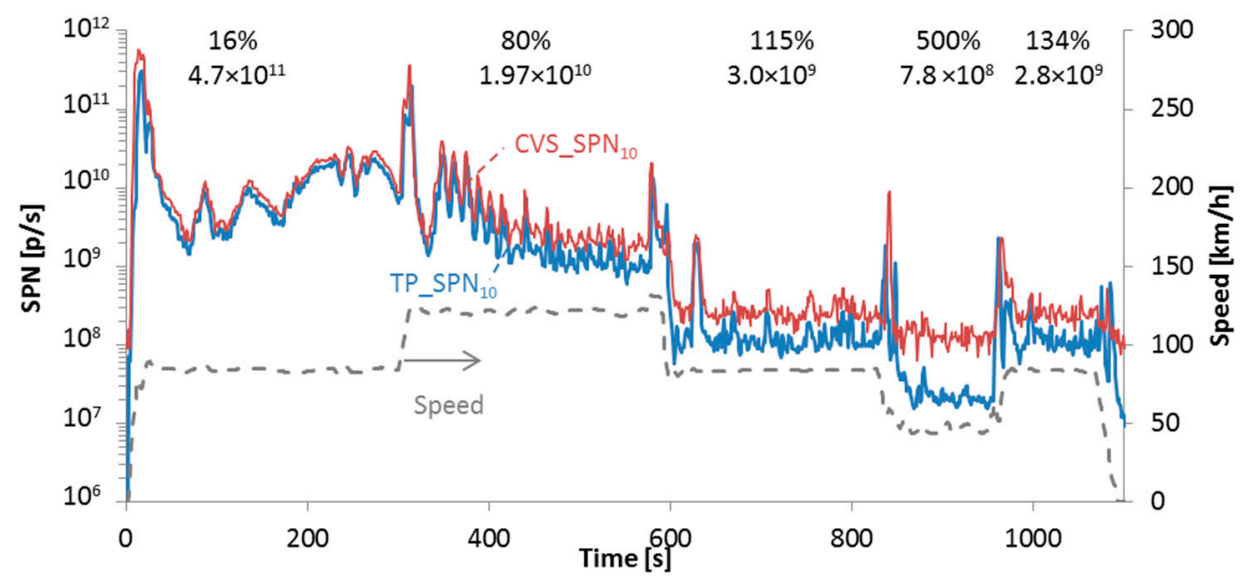

Figure 10. Solid particle number (SPN) emissions $>10 \mathrm{~nm}$ measured the tailpipe (TP) and the full dilution tunnel (CVS) for L3e-A3 \#8. Speed and exhaust gas temperature is also shown. Numbers give $\mathrm{SPN}>10 \mathrm{~nm}$ emissions determined from the tailpipe instrument at the different speeds. Percentages give the differences of the dilution tunnel (CVS) instrument compared to the tailpipe one.

Figure 11 plots the SPN emissions for the moped L1e-B at maximum speed $(45 \mathrm{~km} / \mathrm{h})$ as measured at the tailpipe and at the CVS. There is a good agreement between the two SPN $>23 \mathrm{~nm}$ measurements. The SPN $>10 \mathrm{~nm}$, as determined at the tailpipe are two times higher than the SPN $>23 \mathrm{~nm}$ (after cold start), in agreement with the previously reported fractions (e.g., Figure 10), indicating that the size distribution peaks below $23 \mathrm{~nm}$. However, the SPN $>10 \mathrm{~nm}$ concentration at the dilution tunnel starts to deviate from approximately time $250 \mathrm{~s}$ (exhaust gas temperature at the tailpipe around $250^{\circ} \mathrm{C}$ ). These particles are not a volatile artefact because the instrument had a catalytic stripper and, in addition, a change of the PCRF from 250 to 1500 did not change the measured concentrations.

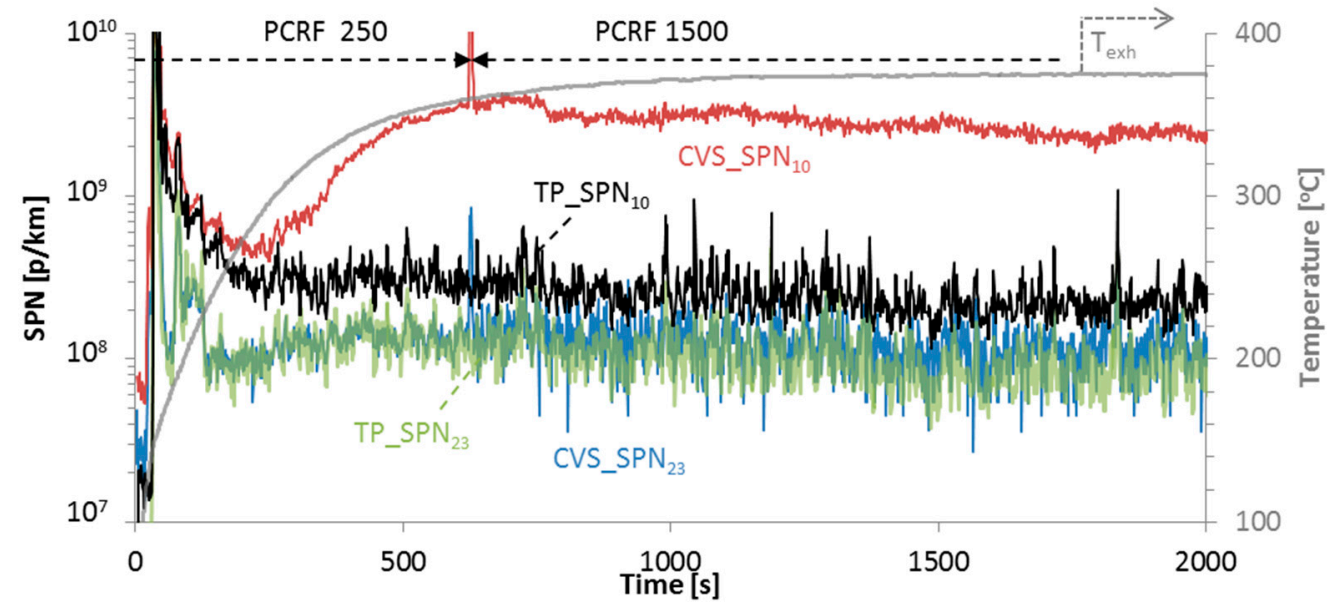

Figure 11. Solid particle number (SPN) emissions $>10 \mathrm{~nm}$ measured at the tailpipe (TP) and the full dilution tunnel (CVS) for the moped L1e-B. The particle number concentration reduction factor (PCRF) changed from 250 to 1500 at $600 \mathrm{~s}$. Speed and exhaust gas temperature is also shown. The measurement system had a catalytic stripper.

As was discussed in another study [60] there are two plausible explanations: (i) non-volatile particle formation in the tube from the vehicle to the dilution tunnel (e.g., due to pyrolysis during 
the $15 \mathrm{~s}$ residence time), or (ii) homogeneously or heterogeneously nucleated and condensed heavy molecular species that cannot evaporate in the system at the dilution tunnel due to the short residence time (around $0.25 \mathrm{~s}$ ) rending the catalytic stripper less effective [52]. This could also explain the high increase of sub-23 nm particles with L3e-A2 \#4 (Figure 9). Why this was not seen with the motorcycle L3e-A3 \#8 (Figure 10) is not clear. It seems that the long residence time in the tubing to the dilution tunnel of the moped (15 s) or L3e-A2 \#4 (3.5 s) favored the non-volatile formation via pyrolysis or due to the low flowrates the heavy molecular species (emitted by the PTW or desorbed from the transfer tube) had time to grow. When the test of the moped was repeated with open tubing (i.e. ambient air entering and diluting directly at the tailpipe) this difference was not seen and the exhaust gas temperature was $<130{ }^{\circ} \mathrm{C}$. Thus, for moped, and in general for small engine displacement L-category vehicles, better definition of the sampling requirements is necessary before introducing SPN measurements in the regulations.

\section{Conclusions}

Particulate mass and number emissions of one moped and eight motorcycles equipped with 4-stroke engines, type-approved as Euro 4, were determined over the recently introduced world-harmonised motorcycle test cycle (WMTC). Particulate matter (PM) mass emissions were below $1.5 \mathrm{mg} / \mathrm{km}$, well below the $4.5 \mathrm{mg} / \mathrm{km}$ limit introduced for Euro 5 powered two-wheelers (PTW) equipped with diesel or gasoline direct injection engines.

Solid particle number (SPN) emissions were determined from the full dilution tunnel using a sampling system equipped with a catalytic stripper to eliminate volatile and semi-volatile interference (artifacts). SPN could be determined with an average repeatability of 10\% (range 1-24\%) over two repetitions per vehicle. Four vehicles were found to exceed the $6 \times 10^{11} \mathrm{p} / \mathrm{km}$ level (particles $>23 \mathrm{~nm}$ ), applicable as a limit for passenger cars. For 3 more vehicles, emissions were close to the level when including particles down to $10 \mathrm{~nm}$.

Compared to older PTWs, emissions of Euro 4 vehicles in this study were at the low end of measured ranges for both the PM mass and number, indicating that technology improvements to achieve $\mathrm{HC}$ and $\mathrm{CO}$ levels were also effective in decreasing particulate emissions. However, there was no clear PM level that would ensure low SPN levels and consequently the two metrics should be considered separately in future regulations. The fact that several Euro 4 vehicles are at or close to the limit level value means that monitoring of SPN emissions for PTWs needs to continue, especially as technology further improves towards Euro 5.

Comparisons of tailpipe and CVS measurements were in relatively good agreement for one motorcycle, but not for the moped. Much higher particle numbers in the 10-23 nm size range were observed following the CVS method compared to measurements at the tailpipe. Semi-volatile material condensation and particle growth might explain this. This is a clear indication that more targeted studies in that direction are required before introducing a measurement protocol for any future SPN regulation of such vehicles.

Author Contributions: Conceptualization, B.G. and A.A.Z.; methodology, A.A.Z., A.P. and L.N.; formal analysis, B.G. and A.K.; writing—original draft preparation, B.G.; writing—review and editing, A.A.Z., A.K., A.P., T.L., and L.N.; supervision, A.A.Z., A.P., and L.N.

Funding: The authors from the European commission received no external funding. The work performed by the authors from the Aristotle University of Thessaloniki was partly funded by the European Commission under the project "Effect study of the environmental step Euro 5 for L-category vehicles" (project number: 060.18277).

Acknowledgments: We are grateful to technical support of the VELA JRC laboratories personnel Dominique Leseuer, Mauro Cadario, Philippe Le Lijour, and Andrea Bonamin. The authors would also like to thank Willar Vonk, Pim van Mensch and Mitch Elstgeest from TNO, Georgios Triantafyllopoulos and Georgios Papadopoulos (Emisia S.A) for their support during the measurement campaign. We would like to thank ACEM - the European Association of Motorcycle Manufacturers for providing some of the vehicles and the staff at Technical University Graz for their assistance.

Conflicts of Interest: The authors declare no conflict of interest. 
Disclaimer: The opinions expressed in this manuscript are those of the authors and should in no way be considered to represent an official opinion of the European Commission. Mention of trade names or commercial products does not constitute endorsement or recommendation by the authors or the European Commission.

\section{Appendix A}

The exhaust flow rates used for the constant speed tests are given in Table A1. For completeness the average exhaust flow rates of the WMTCs are also given. The exhaust flow rates were calculated with the $\mathrm{CO}_{2}$ tracer method.

Table A1. Average exhaust flow rates $\left[\mathrm{m}^{3} / \mathrm{min}\right.$ ] normalised to $0{ }^{\circ} \mathrm{C}$ and $101.3 \mathrm{kPa}$ over various tests.

\begin{tabular}{|c|c|c|c|c|c|c|c|c|}
\hline \multirow[t]{2}{*}{ Code } & \multirow{2}{*}{$\frac{\text { WMTC }}{\text { Speed }[\mathrm{km} / \mathrm{h}]}$} & \multirow{2}{*}{\begin{tabular}{|c|}
1 \\
22.8
\end{tabular}} & \multirow{2}{*}{$\begin{array}{c}2-1 \\
36.8 \mathrm{~km} / \mathrm{h}\end{array}$} & \multirow{2}{*}{$\begin{array}{c}2-2 \\
39.5\end{array}$} & \multirow{2}{*}{\begin{tabular}{|c|}
$3-2$ \\
57.8
\end{tabular}} & \multicolumn{3}{|c|}{ Constant Speeds } \\
\hline & & & & & & 45.0 & 85.0 & 120.0 \\
\hline$\# 1$ & L1e-B & 0.10 & & & & 0.20 & & \\
\hline$\# 2$ & L3e-A1 & 0.10 & & & & & & \\
\hline$\# 3$ & L3e-A2 & & 0.15 & & & & & \\
\hline$\# 4$ & L3e-A2 & & & 0.20 & & & & \\
\hline \#5 & L3e-A2 & & & 0.19 & & & & \\
\hline \#6 & L3e-A2 & & & 0.17 & & & & \\
\hline \#7 & L3e-A2 & & & 0.19 & & & & \\
\hline$\# 8$ & L3e-A3 & & & 0.31 & 0.47 & 0.33 & 0.54 & 1.03 \\
\hline$\# 9$ & L3e-A3 & & & 0.26 & 0.39 & & & \\
\hline
\end{tabular}

\section{References}

1. Health Effects Institute. State of Global Air 2019, Special Report; Health Effects Institute: Boston, MA, USA, 2019.

2. Kumar, P.; Morawska, L.; Birmili, W.; Paasonen, P.; Hu, M.; Kulmala, M.; Harrison, R.M.; Norford, L.; Britter, R. Ultrafine particles in cities. Environ. Int. 2014, 66, 1-10. [CrossRef] [PubMed]

3. Stabile, L.; Massimo, A.; Rizza, V.; D’Apuzzo, M.; Evangelisti, A.; Scungio, M.; Frattolillo, A.; Cortellessa, G.; Buonanno, G. A novel approach to evaluate the lung cancer risk of airborne particles emitted in a city. Sci. Total Environ. 2019, 656, 1032-1042. [CrossRef] [PubMed]

4. Harrison, R.M.; Shi, J.P.; Xi, S.; Khan, A.; Mark, D.; Kinnersley, R.; Yin, J. Measurement of number, mass and size distribution of particles in the atmosphere. Philos. Trans. R. Soc. London. Ser. A Math. Phys. Eng. Sci. 2000, 358, 2567-2580. [CrossRef]

5. World Health Organization Review of Evidence on Health Aspects of Air Pollution-REVIHAAP project. 2013. Available online: http://www.euro.who.int/en/health-topics/environment-and-health/air-quality/ publications/2013/review-of-evidence-on-health-aspects-of-air-pollution-revihaap-project-final-technicalreport (accessed on 19 July 2019).

6. Giechaskiel, B.; Alföldy, B.; Drossinos, Y. A metric for health effects studies of diesel exhaust particles. J. Aerosol. Sci. 2009, 40, 639-651. [CrossRef]

7. Rönkkö, T.; Kuuluvainen, H.; Karjalainen, P.; Keskinen, J.; Hillamo, R.; Niemi, J.V.; Pirjola, L.; Timonen, H.J.; Saarikoski, S.; Saukko, E.; et al. Traffic is a major source of atmospheric nanocluster aerosol. Proc. Natl. Acad. Sci. USA 2017, 114, 7549-7554. [CrossRef]

8. Bousiotis, D.; Dall'Osto, M.; Beddows, D.C.S.; Pope, F.D.; Harrison, R.M. Analysis of new particle formation (NPF) events at nearby rural, urban background and urban roadside sites. Atmos. Chem. Phys. 2019, 19, 5679-5694. [CrossRef]

9. Platt, S.M.; Haddad, I.E.; Pieber, S.M.; Huang, R.-J.; Zardini, A.A.; Clairotte, M.; Suarez-Bertoa, R.; Barmet, P.; Pfaffenberger, L.; Wolf, R.; et al. Two-stroke scooters are a dominant source of air pollution in many cities. Nat. Commun. 2014, 5, 3749. [CrossRef]

10. Guerreiro, C.; González Ortiz, A.; de Leeuw, F.; Viana, M.; Colette, A. Air Quality in Europe - 2018 Report; European Environment Agency, Publications Office of the European Union: Luxembourg, 2018; ISBN 978-92-9213-989-6. 
11. Giechaskiel, B.; Maricq, M.; Ntziachristos, L.; Dardiotis, C.; Wang, X.; Axmann, H.; Bergmann, A.; Schindler, W. Review of motor vehicle particulate emissions sampling and measurement: From smoke and filter mass to particle number. J. Aerosol. Sci. 2014, 67, 48-86. [CrossRef]

12. Giechaskiel, B.; Mamakos, A.; Andersson, J.; Dilara, P.; Martini, G.; Schindler, W.; Bergmann, A. Measurement of automotive nonvolatile particle number emissions within the European legislative framework: A review. Aerosol. Sci. Technol. 2012, 46, 719-749. [CrossRef]

13. Giechaskiel, B.; Joshi, A.; Ntziachristos, L.; Dilara, P. European regulatory framework and particulate matter emissions of gasoline light-duty vehicles: A review. Catalysts 2019, 9, 586. [CrossRef]

14. Martini, G. PMP IWG Progress Report. Available online: https://wiki.unece.org/display/trans/PMP +49 th + Session (accessed on 19 July 2019).

15. Giechaskiel, B.; Vanhanen, J.; Väkevä, M.; Martini, G. Investigation of vehicle exhaust sub-23 nm particle emissions. Aerosol. Sci. Technol. 2017, 51, 626-641. [CrossRef]

16. Giechaskiel, B.; Lähde, T.; Suarez-Bertoa, R.; Clairotte, M.; Grigoratos, T.; Zardini, A.; Perujo, A.; Martini, G. Particle number measurements in the European legislation and future JRC activities. Combust. Engines 2018, 174, 3-16.

17. Giechaskiel, B.; Lähde, T.; Drossinos, Y. Regulating particle number measurements from the tailpipe of light-duty vehicles: The next step? Environ. Res. 2019, 172, 1-9. [CrossRef] [PubMed]

18. Iodice, P.; Senatore, A. Exhaust emissions of new high-performance motorcycles in hot and cold conditions. Int. J. Environ. Sci. Technol. 2015, 12, 3133-3144. [CrossRef]

19. European Commission-Directorate General for Mobility and Transport. EU Transport in Figures: Statistical Pocketbook; Publications Office of the European Union: Luxembourg, 2018; ISBN 978-92-79-73951-4.

20. ACEM Association des Constructeurs Européens de Motocycles. Market data. Available online: https: //www.acem.eu/market-data (accessed on 19 July 2019).

21. Ntziachristos, L.; Giechaskiel, B.; Pistikopoulos, P.; Fysikas, E.; Samaras, Z. Particle emissions characteristics of different on-road vehicles. SAE Trans. 2003, 112, 1568-1578.

22. Ntziachristos, L.; Pistikopoulos, P.; Samaras, Z. Particle characterization from two-stroke powered two-wheelers. Int. J. Engine. Res. 2005, 6, 263-275. [CrossRef]

23. Czerwinski, J.; Comte, P.; Napoli, S.; Wili, P. Summer cold start and nanoparticulates of small scooters. $S A E$ Tech. Pap. 2002. [CrossRef]

24. Czerwinski, J.; Comte, P.; Reutimann, F. Nanoparticle emissions of a DI 2-stroke scooter with varying oil- \& fuel quality. SAE Trans. 2005, 114, 541-596.

25. Czerwinski, J.; Comte, P.; Larsen, B.; Martini, G.; Mayer, A. Research on particle emissions of modern 2-stroke scooters. SAE Tech. Pap. 2006. [CrossRef]

26. Czerwinski, J.; Comte, P.; Makkee, M.; Reutimann, F. (Particle) emissions of small 2- \& 4-stroke scooters with (hydrous) ethanol blends. SAE Tech. Pap. 2010. [CrossRef]

27. Favre, C.; May, J.; Bosteels, D.; Tromayer, J.; Neumann, G.; Kirchberger, R.; Eichlseder, H. Regulated and Non-Regulated Emissions of Selected State-of-the-Art European Mopeds. In Proceedings of the SIA 2011 Congress, Strasbourg, France, 30 November 2011.

28. Santino, D.; Picini, P.; Martino, L. Particulate matter emissions from two-stroke mopeds. SAE Tech. Pap. 2001. [CrossRef]

29. Yang, H.; Hsieh, L.; Liu, H.; Mi, H. Polycyclic aromatic hydrocarbon emissions from motorcycles. Atmos. Environ. 2005, 39, 17-25. [CrossRef]

30. Spezzano, P.; Picini, P.; Cataldi, D.; Messale, F.; Manni, C. Particle- and gas-phase emissions of polycyclic aromatic hydrocarbons from two-stroke, 50- $\mathrm{cm}^{3}$ mopeds. Atmos. Environ. 2008, 42, 4332-4344. [CrossRef]

31. Adam, T.; Farfaletti, A.; Montero, L.; Martini, G.; Manfredi, U.; Larsen, B.; Santi, G.D.; Krasenbrink, A.; Astorga, C. Chemical characterization of emissions from modern two-stroke mopeds complying with legislative regulation in Europe (Euro-2). Environ. Sci. Technol. 2010, 44, 505-512. [CrossRef]

32. Clairotte, M.; Adam, T.W.; Chirico, R.; Giechaskiel, B.; Manfredi, U.; Elsasser, M.; Sklorz, M.; DeCarlo, P.F.; Heringa, M.F.; Zimmermann, R.; et al. Online characterization of regulated and unregulated gaseous and particulate exhaust emissions from two-stroke mopeds: A chemometric approach. Analytica Chimica Acta 2012, 717, 28-38. [CrossRef]

33. Prati, M.V.; Costagliola, M.A. Emissions of fine particles and organic compounds from mopeds. Environ. Eng. Sci. 2009, 26, 111-122. [CrossRef] 
34. Zardini, A.A.; Platt, S.M.; Clairotte, M.; El Haddad, I.; Temime-Roussel, B.; Marchand, N.; Ježek, I.; Drinovec, L.; Močnik, G.; Slowik, J.G.; et al. Effects of alkylate fuel on exhaust emissions and secondary aerosol formation of a 2-stroke and a 4-stroke scooter. Atmos. Environ. 2014, 94, 307-315. [CrossRef]

35. Andersson, J.D.; Lance, D.L.; Jemma, C.A. DfT motorcycle emissions measurement programmes: Unregulated emissions results. SAE Tech. Pap. 2003. [CrossRef]

36. Martini, G.; Astorga, G.; Adam, T.; Bonnel, P.; Farfaletti, A.; Junninen, H.; Manfredi, U.; Montero, L.; Müller, A.; Krasenbrink, A.; et al. Physical \& Chemical Characterization of Emissions from 2-Stroke Motorcycles: (Comparison with 4-Stroke Engines); Office for Official Publications of the European Communities: Luxembourg, 2009.

37. Momenimovahed, A.; Olfert, J.S.; Checkel, M.D.; Pathak, S.; Sood, V.; Singh, Y.; Singal, S.K. Real-time driving cycle measurements of ultrafine particle emissions from two wheelers and comparison with passenger cars. Int. J. Automot. Technol. 2014, 15, 1053-1061. [CrossRef]

38. Czerwinski, J.; Comte, P. Limited emissions and nanoparticulates of a scooter with 2-stroke direct injection (TSDI). SAE Tech. Pap. 2003. [CrossRef]

39. Seggiani, M.; Prati, M.V.; Costagliola, M.A.; Puccini, M.; Vitolo, S. Bioethanol-gasoline fuel blends: Exhaust emissions and morphological characterization of particulate from a moped engine. J. Air. Waste. Manag. Assoc. 2012, 62, 888-897. [CrossRef]

40. Mayer, A.; Czerwinski, J.; Kasper, M.; Ulrich, A.; Mooney, J.J. Metal oxide particle emissions from diesel and petrol engines. SAE Tech. Pap. 2012. [CrossRef]

41. Favre, C.; Bosteels, D.; May, J.; De Souza, I.; Beale, L.; Andersson, J. An emissions performance evaluation of state-of-the-art motorcycles over Euro 3 and WMTC drive cycles. SAE Tech. Pap. 2009. [CrossRef]

42. Spezzano, P.; Picini, P.; Cataldi, D.; Messale, F.; Manni, C.; Santino, D. Particle-phase polycyclic aromatic hydrocarbon emissions from non-catalysed, in-use four-stroke scooters. Environ. Monit. Assess. 2007, 133, 105-117. [CrossRef]

43. Costagliola, M.A.; Prati, M.V.; Florio, S.; Scorletti, P.; Terna, D.; Iodice, P.; Buono, D.; Senatore, A. Performances and emissions of a 4-stroke motorcycle fuelled with ethanol/gasoline blends. Fuel 2016, 183, 470-477. [CrossRef]

44. Kontses, A.; Ntziachristos, L.; Zardini, A.A.; Papadopoulos, G.; Giechaskiel, B. Particulate emissions from L-Category vehicles towards Euro 5. Environ. Res. 2019. submitted.

45. Ntziachristos, L.; Vonk, W.A.; Papadopoulos, G.; van Mensch, P.; Geivanidis, S.; Mellios, G.; Papadimitriou, G.; Steven, H.; Elstgeest, M.; Ligterink, N.E.; et al. Effect Study of the Environmental Step Euro 5 for L-category Vehicles; European Commission: Brussels, Belgium, 2017; ISBN 978-92-79-70203-7.

46. Giechaskiel, B.; Zardini, A.; Martini, G. Particle emission measurements from L-category vehicles. SAE Int. J. Engines 2015, 8, 2322-2337. [CrossRef]

47. Giechaskiel, B.; Arndt, M.; Schindler, W.; Bergmann, A.; Silvis, W.; Drossinos, Y. Sampling of non-volatile vehicle exhaust particles: A simplified guide. SAE Int. J. Engines. 2012, 5, 379-399. [CrossRef]

48. Czerwinski, J.; Comte, P.; Mayer, A.; Reutimann, F. Investigations of changes of the 2-stroke scooters nanoparticles in the exhaust- and cvs-system. SAE Tech. Pap. 2013. [CrossRef]

49. Giechaskiel, B.; Chirico, R.; DeCarlo, P.F.; Clairotte, M.; Adam, T.; Martini, G.; Heringa, M.F.; Richter, R.; Prevot, A.S.H.; Baltensperger, U. Evaluation of the particle measurement programme (PMP) protocol to remove the vehicles' exhaust aerosol volatile phase. Sci. Total. Environ. 2010, 408, 5106-5116. [CrossRef]

50. Giechaskiel, B.; Cresnoverh, M.; Jörgl, H.; Bergmann, A. Calibration and accuracy of a particle number measurement system. Meas. Sci. Technol. 2010, 21, 045102. [CrossRef]

51. Giechaskiel, B.; Manfredi, U.; Martini, G. Engine exhaust solid sub-23 nm particles: I. literature survey. $S A E$ Int. J. Fuels. Lubr. 2014, 7, 950-964. [CrossRef]

52. Amanatidis, S.; Ntziachristos, L.; Giechaskiel, B.; Katsaounis, D.; Samaras, Z.; Bergmann, A. Evaluation of an oxidation catalyst ("catalytic stripper") in eliminating volatile material from combustion aerosol. J. Aerosol. Sci. 2013, 57, 144-155. [CrossRef]

53. Giechaskiel, B.; Wang, X.; Horn, H.-G.; Spielvogel, J.; Gerhart, C.; Southgate, J.; Jing, L.; Kasper, M.; Drossinos, Y.; Krasenbrink, A. Calibration of condensation particle counters for legislated vehicle number emission measurements. Aerosol. Sci. Technol. 2009, 43, 1164-1173. [CrossRef]

54. Wang, X.; Caldow, R.; Sem, G.J.; Hama, N.; Sakurai, H. Evaluation of a condensation particle counter for vehicle emission measurement: Experimental procedure and effects of calibration aerosol material. J. Aerosol. Sci. 2010, 41, 306-318. [CrossRef] 
55. Takegawa, N.; Sakurai, H. Laboratory evaluation of a TSI condensation particle counter (model 3771) under airborne measurement conditions. Aerosol. Sci. Technol. 2011, 45, 272-283. [CrossRef]

56. Yamada, H.; Funato, K.; Sakurai, H. Application of the PMP methodology to the measurement of sub-23 nm solid particles: Calibration procedures, experimental uncertainties, and data correction methods. J. Aerosol. Sci. 2015, 88, 58-71. [CrossRef]

57. Joshi, A.; Johnson, T. Gasoline particulate filters-A review. Emiss. Control. Sci. Technol. 2018, 4, $219-239$. [CrossRef]

58. Maricq, M.M.; Szente, J.; Loos, M.; Vogt, R. Motor vehicle PM emissions measurement at LEV III levels. SAE Int. J. Engines 2011, 4, 597-609. [CrossRef]

59. Chase, R.E.; Duszkiewicz, G.J.; Richert, J.F.O.; Lewis, D.; Maricq, M.M.; Xu, N. PM measurement artifact: organic vapor deposition on different filter media. SAE Tech. Pap. 2004. [CrossRef]

60. Giechaskiel, B. Differences between tailpipe and dilution tunnel sub-23 nm non-volatile (solid) particle number measurements. Aerosol. Sci. Technol. 2019,1-13. [CrossRef]

(C) 2019 by the authors. Licensee MDPI, Basel, Switzerland. This article is an open access article distributed under the terms and conditions of the Creative Commons Attribution (CC BY) license (http://creativecommons.org/licenses/by/4.0/). 